УДК 502.17

\title{
СУЧАСНИЙ СТАН ВИРОБНИЦТВА ЛІКАРСЬКОЇ РОСЛИННОЇ СИРОВИНИ В УКРӒ̈НІ
}

\author{
H.I. Паляничко \\ доктор економі нних наук, старший науковий співробітник \\ Національна академія аграрних наук України \\ (Україна, м. Київ; e-mail: spalianychko@ukr.net) \\ С.Я. Ольхович \\ Інститут агроекології і природокористування НАAН \\ (Україна, м. Київ; e-mail: sv.olkhovych@ukr.net) \\ O.B. Крохтяк \\ кандидат економі чних наук \\ Інститут агроекології і природокористування НАAH \\ (Україна, м. Київ; e-mail: lesja26051988@gmail.com)
}

\begin{abstract}
Проаналізовано стан виробництва лікарсъкої рослинної сировини в Україні. Встановлено, шо ебективність використання боторізноманіття бблори у нашій країні для медичних иілей є однією з найвищих у світі. Найпоширенішими лікарсъкими рослинали є валеріана, шипшина, gбіалка триколірна, шавлія, кульбаба, материнка звичайна, барвінок малий, суниця лісова, ромашка та ін. Сприятливили для вирошування та збирання лікарсъкої сировини є зони: Карпати, Лісостеп, Полісся, несприятливою - зона Степу. Через несприятливі погодні умови впродовж $2006-2016$ рр. заготівля лікарсъкої сировини знизиласъ у 5,5 раза. Найбілъшими компаніяли, які зайлаються лікарсъкою рослинною сировиною є: ТОВ «Фітосвіт ЛТ Д» (вирошування та оптовий продаж лікарсъких трав і рослин), ЗАТ «Ліктрави» (Житомир) (виробництво gbimопрепаратів та gbiточаїв), ВАТ "Галичфбарл» (виробництво лікарсъких засобів на основі екстракиї рослинної лікарсъкої сировини), "Сумибітоббармачія» (вирошування, збирання, перероблення, виробництво і постачання сировини для виробництва чаю). Найбілъші підприєлства, що зайлаютъся вирощуванням лікарсъкої рослинної сировини розташовані в Полтавсъкій (ТОВ «Полтава-сад»), Херсонсъкій (ТОВ “Дніпро-Білогір'я»), Рівненсъкій (ТОВ «Полісъкий стандарт»), Одесъкій (ТОВ «Південъ агропереробка»), Чернігівсъкій (ТОВ «Прогрес»), Черкасъкій (ФГ «Восход») та Донецъкій (ПП "Дон Івко І С») областях.
\end{abstract}

Ключові слова: лікарсъкі рослини, рослинна сировина, посівні площі, обсяги виробництва.

Постановка проблеми. Здавна людство використовувало лікарські рослини як для лікування так і для профілактики різних недугів. На сьогодні, незважаючи на розвиток традиційної медицини, зростає попит на лікарські рослинні препарати. Про це свідчить стрімкість реалізації препаратів рослинного походження. В Україні лікарські препарати представлені ресурсами зарубіжного виробництва, хоча наша країна є ключовою серед країн, де вирощується і заготовлюється лікарська рослинна сировина. При такій ситуації, необхідним є одержання високих врожаїв та якісної лікарської продукції.

Аналіз останніх досліджень і публікацій. Дослідженнями у сфері забезпечення галузей національної економіки ресурсами, зокрема лікарськими, займалося багато вітчизняних та зарубіжних вчених таких як: O.I. Фурдичко, П.Т. Саблук, М.Х. Шершун, О.В. Скидан, I.M. Лицур, Дж. Кейнс, Ф. Кене, Ф. Котлер та ін. Однак, на сьогодні недостатньо вивчені пи- тання, пов'язані з заготівлею, вирощуванням та виробництвом лікарської рослинної сировини.

Метою дослідження є аналіз сучасного стану та тенденцій розвитку виробництва лікарської рослинної сировини в Україні, а також визначення основних стримуючих чинників розвитку галузі лікарського рослинництва.

Матеріали та методи. Для досягнення мети нами було використано статистичний (аналіз сучасного стану виробництва лікарської рослинної сировини) та графічний (презентація економічних показників заготівлі лікарської сировини) методи дослідження.

Виклад основного матеріалу дослідження. Згідно із Законом України «Про насіння i садивний матеріал», лікарські рослини - це дикорослі та культурні рослини або їні частини (насіння, бруньки, квіти, плоди, стебла, кореневища), що використовуються в медицині для виготовлення лікарських препаратів [1]. За офіційними даними в Україні близько 200 ви- 
дів рослин використовується у лікарському виробництві. Основним джерелом постачання лікарської сировини є дикорослі, культивовані, а також імпортовані рослини. Зауважимо, що останніми роками стан заготівлі дикорослих рослин погіршився, оскільки активна господарська діяльність людини призвела до знищення багатьох видів лікарських рослин. В Україні можливо вирощувати близько 60 видів лікарських рослин, 3 яких тільки 25 - культивуються. Не менш важливим джерелом постачання $\epsilon$ імпортована лікарська сировина, яка не вирощується у нашій країні, але використовується для виготовлення лікарських препаратів [2].

За даними Всесвітньої організації охорони здоров' я близько 80\% жителів нашої планети використовують лікарські рослини, біологічно-активні добавки рослинного походження для лікування та профілактики різних недугів. Понад 52 тис. видів рослин використовуються як лікарські. Для медичних потреб з 400 тис. видів використовують 20 тис., а деякі науковці вважають, що ця цифрра може сягати 50 або 70 тис. Слід наголосити, що під загрозою зникнення перебувають 15 тис. видів лікарських рослин [3].

У різних країнах світу ефективність використання фрлори є неоднаковою. Так, в Україні з 2219 видів лікарських рослин, що використовуються у сорері гуманної ветеринарної і народної медицини (табл. 1), 10\% (244) - культивовані, інтродуковані види, решта - дикорослі. 3 244 видів культивованих рослин - 32 види є сільськогосподарськими культурами; 29 - плодово-ягідними; 150 видів рослин вирощуються для одержання лікарської сировини; решта зростає у садах, приватних колекціях та паркax [3].

Як бачимо з табл. 1, Україна найефективніше використовує біоресурси для медичних потреб серед інших країн світу, що свідчить про можливість лідерського представництва на світовому ринку з вирощування лікарської рослинної сировини.

Нашою державою експортується низка лікарських рослин, як-от: каштан, розторопша п'ятниста, бузина, бруньки та листя берези, кропива, кора крушини, ехінацея, чистотіл, звіробій, рильця кукурудзи, хвощ, безсмертник, аїр, люпин, насіння гарбуза, коріандр, льон тощо, що підтверджує позитивні тенденції у розвитку лікарського рослинництва загалом. Українські виробники реалізують за кордон доволі широкий діапазон продукції — найбільша питома вага припадає на ехінацею $(35,82 \%)$, каштан $(17,08)$, розторопшу $(10,36)$, бузину $(5,68 \%)$ [12]. Водночас слід наголосити на можливості розширення експорту готової продукції з лікарської сировини. Наприклад, на частку Індії припадає близько $25 \%$ світового

Таблицяя 1

Ефективність використання фіторізноманіття фолори для медичних цілей у різних країнах світу

\begin{tabular}{|l|c|c|c|}
\hline \multicolumn{1}{|c|}{ Країна } & Фіторізноманіття & Лікарські види & Ефективність, \% \\
\hline \hline Китай & 32200 & 4941 & 15,3 \\
\hline Індія & 18664 & 3000 & 4,4 \\
\hline Індонезія & 22500 & 1000 & 7,7 \\
\hline Малайзія & 15500 & 1200 & 10,0 \\
\hline Непал & 6973 & 700 & 6,0 \\
\hline Пакистан & 4950 & 300 & 9,5 \\
\hline Філіппіни & 8931 & 850 & 16,5 \\
\hline Шрі Ланка & 3314 & 550 & 15,4 \\
\hline Таїланд & 11625 & 1800 & 11,8 \\
\hline США & 21641 & 2564 & 17,1 \\
\hline В'єтнам & 10500 & 1800 & 36,4 \\
\hline Україна & 6068 & 2219 & 20,2 \\
\hline Польща & 2468 & 500 & 21,5 \\
\hline Болгарія & 3567 & 770 & 12,5 \\
\hline Всього у світі & 422000 & 52885 & \\
\hline
\end{tabular}

Джерело: сорормовано за [3]. 
експорту олеорезину календули, а на частку Китаю - близько 50\% [13]. Вагомим експортером і потужною компанією у сорері вітчизняного лікарського рослинництва є ТОВ «Сумифітофармація», чия продукція продається як на ринках країн СНД, так і на ринках Європи, Америки та Азії [12].

В Україні вирощують валеріану, шипшину, фріалку триколірну, шавлію, дурман, кульбабу, материнку звичайну, барвінок малий, лепеху звичайну, суницю лісову, ромашку, брусницю, чорну смородину, чорницю, малину, калину, лаванду, м'яту перцеву, кропиву, чистотіл, звіробій, подорожник, обліпиху, конвалію та багато інших лікарських рослин. Збирають лікарську рослинну сировину у природно-кліматичних зонах Карпат, Лісостепу, Полісся. Менш придатною для вирощування та збирання є зона Степу [4-6]. У структурі імпорту лікарських рослин до України лідирує ромашка, хоча є традиційною культурою для нашої держави. У значних обсягах імпортується також базилік, корінь валеріани, календула, м'ята - культури, які можна вирощувати в Україні й тим самим розвивати вітчизняне лікарське рослинництво та фрармацевтичне виробництво [12].

Сьогодні лікарську рослинну сировину постачають фермери, лісові господарства, приватні особи. І лише частина 3 них обробляють та заготовляють лікарську сировину [7]. Попит на лікарську рослинну сировину щорічно збільшується майже на 20\% [8]. Найбільшими споживачами лікарської рослинної сировини є харчова промисловість, виробники чаїв, фрармацевтичні компанії, косметологія та ін.
До 2014 р. в Україні найбільшим виробником лікарської рослинної сировини було ТОВ «Фіторадгосп «Веселка», де щорічно заготовляли близько 1 тис. т лікарської сировини. Тут збирали та заготовляли квітки липи, бузини, трави фріалки триколірної, розторопші, майорану садового, каланхое, кмину звичайного, пижма, подорожника, дурману звичайного, анісу звичайного та ін. [9].

Ще одним потужним виробником лікарської сировини є ТОВ «Фітосвіт ЛТД». Основною діяльністю компанії є вирощування та оптовий продаж лікарських трав, рослин та насіння. Також компанія продає сировину дикорослих лікарських рослин на замовлення. Заслуговує на увагу також найбільший виробник лікарських засобів з рослинної сировини ЗАТ «Ліктрави» (Жћитомир), що займається виробництвом фрітопрепаратів, фріточаїв, профрілактичних, оздоровчих фрітованн.

Лідером у сорері виробництва готових лікарських засобів на основі екстракції рослинної лікарської сировини є ВАТ «Галичфрарм». Виробництво налічує близько 90 оригінальних лікарських засобів. Підприємство ТОВ «Сумифітофрармація» займається вирощуванням, збиранням, переробленням, виробництвом і постачанням сировини для чаю. Також виробляє готову або напівготову продукцію для споживання.

Найбільшими виробниками лікарської рослинної сировини є підприємства у Полтавській, Херсонській, Рівненській, Одеській, Чернігівській, Черкаській, Донецькій областях (табл. 2), площі під посівами лікарських рослин яких займають майже 1200 га [10]. У табл. 2

Таблиияя 2

Найбільші підприємства України, що вирощують лікарську рослинну сировину

\begin{tabular}{|l|l|}
\hline \multicolumn{1}{|c|}{ Регіон/Область } & \multicolumn{1}{c|}{ Підприсмство } \\
\hline \hline АР Крим & ТОВ «Фіторадгосп «Веселка» \\
\hline Вінницька & ТОВ «Фітосвіт ЛТД» \\
\hline Сумська & ТОВ «Суиоітофрармація» \\
\hline Полтавська & ТОВ «Полтава-сад» \\
\hline Херсонська & ТОВ «Дніпро-Білогір’я» \\
\hline Донецька & ПП «Дон Івко І С» \\
\hline Чернігівська & ТОВ «Прогрес» \\
\hline Рівненська & ТОВ «Поліський стандарт» \\
\hline Одеська & ТОВ «Південьагропереробка» \\
\hline Черкаська & ФГ «Восход» \\
\hline
\end{tabular}




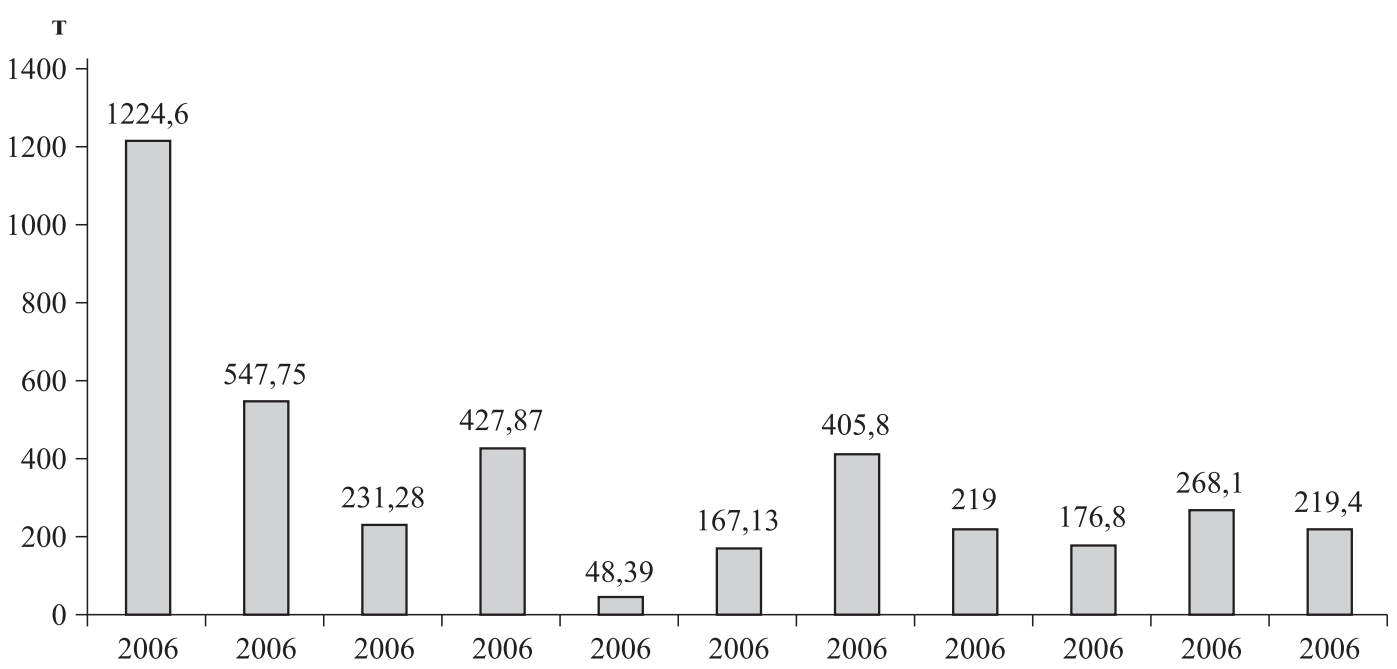

Рік

Рис. 1. Динаміка заготівлі лікарсъкої рослинної сировини в Україні, 2006-2016 рр., m Джерело: за даними [10].

наведено найбільші підприємства України з вирощування лікарської рослинної сировини.

Як свідчать дослідження [11], в Україні середня частка угідь під лікарськими рослинами у розрізі сільськогосподарських земель у 2017 р. становила лише 0,15\%. Поряд із тим площа, зайнята лікарськими рослинами, становить близько 60 тис. га, що підтверджує важливість вказаної галузі рослинництва.

Динаміка заготівлі лікарської сировини впродовж 2006-2016 рр. знизилась у 5,5 раза (рис. 1). Вчені вважають [11], що чинником зниження вказаного показника можуть бути несприятливі погодно-кліматичні умови, природні і техногенні ситуації. Також заготівля лікарської рослинної сировини у природних умовах залежить від низки економічних показників, як-от: нестабільна економічна ситуація у країні, попит-пропозиція на продукцію на ринку тощо.

Так, у господарствах усіх категорій у 2016 р. обсяги виробництва та посівні площі лікарських рослин були більшими, ніж у 2017 р. (табл. 3). Така сама ситуація спостерігається і у сільськогосподарських підприємствах щодо обсягів виробництва та посівних площ лікарських рослин. У господарствах населення ситуація не змінилась — обсяги виробництва та посівні площі лікарських рослин були однаковими упродовж досліджень. Це свідчить про те, що 2016 р. був сприятливішим як у фрінансовому аспекті, так і щодо погодних умов.

Таблиияя 3

Вирощування лікарських рослин у 2016-2017 pp.

\begin{tabular}{|c|c|c|c|c|c|c|}
\hline \multirow{2}{*}{$\begin{array}{l}\text { Лікарські } \\
\text { рослини }\end{array}$} & \multicolumn{2}{|c|}{$\begin{array}{l}\text { Господарства } \\
\text { усіх категорій }\end{array}$} & \multicolumn{2}{|c|}{$\begin{array}{c}\text { Сільськогосподарські } \\
\text { підприємства }\end{array}$} & \multicolumn{2}{|c|}{ Господарства населення } \\
\hline & $\begin{array}{c}\text { площа } \\
\text { посівна, } \\
\text { тис. га }\end{array}$ & $\begin{array}{c}\text { обсяг } \\
\text { виробництва, } \\
\text { тис. ц /га }\end{array}$ & $\begin{array}{c}\text { площа } \\
\text { посівна, } \\
\text { тис. га }\end{array}$ & $\begin{array}{c}\text { обсяг } \\
\text { виробництва, } \\
\text { тис. ц /га }\end{array}$ & $\begin{array}{c}\text { площа } \\
\text { посівна, } \\
\text { тис. га }\end{array}$ & $\begin{array}{c}\text { обсяг } \\
\text { виробництва, } \\
\text { тис. ц/га }\end{array}$ \\
\hline \multicolumn{7}{|c|}{2016} \\
\hline $\begin{array}{l}\text { Рослини лікар- } \\
\text { ські, у т.ч.: }\end{array}$ & 7,3 & 66,3 & 7,3 & 62,4 & 0,0 & 3,9 \\
\hline ромашка & 0,4 & 2,3 & 0,4 & 2,3 & 0,0 & 0,0 \\
\hline валеріана & 0,0 & 1,7 & 0,0 & 1,7 & 0,0 & 0,0 \\
\hline шипшина & 0,0 & 0,1 & - & - & 0,0 & 0,1 \\
\hline насіння гарбуза & 3,2 & 29,4 & 3,2 & 29,3 & 0,0 & 0,1 \\
\hline нагідки & 0,0 & 0,1 & 0,0 & 0,1 & 0,0 & 0,0 \\
\hline
\end{tabular}


Закінчення таблиці 1

\begin{tabular}{|c|c|c|c|c|c|c|}
\hline \multirow{2}{*}{$\begin{array}{l}\text { Лікарські } \\
\text { рослини }\end{array}$} & \multicolumn{2}{|c|}{$\begin{array}{c}\text { Господарства } \\
\text { усіх категорій }\end{array}$} & \multicolumn{2}{|c|}{$\begin{array}{c}\text { Сільськогосподарські } \\
\text { підприємства }\end{array}$} & \multicolumn{2}{|c|}{ Господарства населення } \\
\hline & $\begin{array}{c}\text { площа } \\
\text { посівна, } \\
\text { тис. га }\end{array}$ & $\begin{array}{c}\text { обсяг } \\
\text { виробництва, } \\
\text { тис. ц / га }\end{array}$ & $\begin{array}{c}\text { площа } \\
\text { посівна, } \\
\text { тис. га }\end{array}$ & $\begin{array}{c}\text { обсяг } \\
\text { виробництва, } \\
\text { тис. ц /га }\end{array}$ & $\begin{array}{c}\text { площа } \\
\text { посівна, } \\
\text { тис. га }\end{array}$ & $\begin{array}{c}\text { обсяг } \\
\text { виробництва, } \\
\text { тис. ц/га }\end{array}$ \\
\hline собача кропива & 0,0 & 0,4 & 0,0 & 0,4 & 0,0 & - \\
\hline \multicolumn{7}{|c|}{2017} \\
\hline $\begin{array}{l}\text { Рослини } \\
\text { лікарські, у т.ч.: }\end{array}$ & 4,8 & 41,3 & 4,8 & 37,4 & 0,0 & 3,9 \\
\hline ромашка & 0,5 & 4,5 & 0,5 & 4,5 & 0,0 & 0,0 \\
\hline валеріана & 0,0 & 1,3 & 0,0 & 1,3 & 0,0 & 0,0 \\
\hline шипшина & 0,0 & 1,3 & 0,0 & 0,1 & 0,0 & 0,1 \\
\hline насіння гарбуза & 3,2 & 20,1 & 3,2 & 20,1 & 0,0 & 0,1 \\
\hline $\begin{array}{l}\text { рослини лікар- } \\
\text { ські інші }\end{array}$ & 1,0 & 14,9 & 1,0 & 14,9 & 0,0 & 3,5 \\
\hline
\end{tabular}

Джерело: за даними [10]

3 наведеного вище можна констатувати, що на виробництво лікарської рослинної сировини впливає низка чинників: несприятливі погодні умови, природні і техногенні ситуації, нестабільність в економічній сфері. Також для збільшення виробництва лікарської сировини необхідною є підготовка кваліфікованих спеціалістів із її заготівлі, зберігання та переробки. Але незважаючи на цю складну ситуацію, виробництво рослинної сировини продовжує нарощувати свої обсяги відповідно до зростаючого попиту на відповідні лікарські препарати з неї. Таке виробництво здійснюється з урахуванням нових технологій виробництва, розвитку наукової бази, маркетингової і логістичної діяльності підприємств [11].
Висновки. На виробництво лікарської рослинної сировини впливає багато чинників. Це можуть бути як природно-кліматичні, несприятливі погодні умови, так і фінансові та організаційно-виробничі проблеми. Україна є потужним виробником лікарської рослинної сировини, що виводить її у лідери за ефективністю використання у медичних цілях. Збільшується попит на препарати рослинного походження, що робить цю галузь популярною і серед населення. Використовують лікарську рослинну сировину у своїй діяльності також косметологи, харчова промисловість та інші галузі економіки. Тому наші подальші дослідження будуть спрямовані на вивчення чинників, які стримують розвиток лікарського виробництва, та на майбутні його перспективи.

\section{СПИСОК ВИКОРИСТАНИХ ДЖЕРЕЛ}

1. Про насіння і садивний матеріал: Закон України від 26.12.2002. №411-IV. URL: http://zakon.rada. gov.ua/laws/show/411-15.

2. Фудичко О.І., Паук М.Ф. Лікарські та медоносні рослини Галичини / Львів. Світ, 1998, 128 с.

3. Звіт про науково-дослідну роботу «Лікарські рослини, що містять алкалоїди, та можуть бути вирощені з насіннєвого матеріалу ДСЛР ІАП НААН». Березоточа, 2016. 24 с.

4. Лікарські рослини, іх поширення та застосування. Лікарські рослини. [Електронний ресурс]. Режим доступу: http://www. likarski-travi.ks.ua (дата звернення 06.05.2019р.).

5. Лікарські рослини: Енциклопедичний довідник / відп. ред. А.М. Гродзінський. К.: «Українська радянська енциклопедія», 1992. 544 с.

6. Обзор рынка лекарственного растительного сырья Украины 2016: [аналитическийсборник] / Маркетинговая компания Синергия, 2017. 38 с.

7. Порада О. А. Генетичні ресурси лікарських рослин: збереження, вивчення та використання // Генетичні ресурси рослин. 2011. № 9. С. 27-36.

8. Семак Б.Б., Барна М.Ю., Демкевич Л.І. Вітчизняний ринок лікарської рослинної сировини: проблеми і рішення // Науковий вісник НЛтУ України. 2011. Вип. 21.1. С. 264-268. 
9. Никитюк Ю.А. Еколого-економічні засади розвитку ринку лікарської рослинної сировини в Україні: дис. ... д-ра екон. наук: 08.00.06 / Київ, 2017. 452 с.

10. Державної служби статистики України. офіційний інтернет-сайт [Електронний ресурс]. Режим доступу: http://www.ukrstat.gov.ua/

11. Сологуб Ю.О. Еколого-економічний механізм збалансованого розвиткулікарського рослинництва: дис...канд. екон. наук: 08.00.06 / Київ, 2018. 204 с.

12. Мірзоєва Т. В. Особливості експорту-імпорту продукції лікарського рослинництва в умовах сьогодення // Бізнесінфрорм. 2018. № 7. С. 32-37. [Електронний ресурс]. Режим доступу: http://www. business-inform.net/export_pdf/business-inform-2018-7_0-pages-32_37.pdf

13. Sudha Narayanan. Inflectionsin Agricultural Evolution: Contemporary Commodity Complexes and Transactional Formsin Interior Tamil Nadu. Economic\&Political Weekly. Dec 29, 2012. URL: http:// bi.galegroup.com.ezproxy1.lib.asu.edu/global/article/GALE\%7CA313300027?u=asuniv.

\section{Інформація про автора}

Паляничко Ніна Іванівна — доктор економічних наук, старший науковий співробітник, начальник відділу з координації наукових досліджень науково-організаційного управління, Національна академія аграрних наук України (Україна, 01010, м. Київ, вул. Михайла Омеляновича-Павленка, 9; e-mail: spalianychko@ukr.net)

Ольхович Світлана Яремівна - здобувач, завідувач відділу економіки науково-дослідних робіт, Інституту агроекології і природокористування НАAН (Україна, 03143, м. Київ, вул. Метрологічна, 12; e-mail: sv.olkhovych@ukr.net)

Крохтяк Олександра Василівна - кандидат економічних наук, завідувач сектору економічного аналізу науково-дослідних робіт відділу економіки науково-дослідних робіт, Інститут агроекології і природокористування НАAН (Україна, 03143, м. Київ, вул. Метрологічна, 12; е-маil: lesja26051988@gmail.com)

N.I. Palianychko

Doctor of Economic Sciences, Senior Research Fellow National Academy of Agrarian Sciences of Ukraine (Ukraine, Kyiv; e-mail: spalianychko@ukr.net)

S.Ya. Olkhovych Institute of Agroecology and Environmental Management of NAAS (Ukraine, Kyiv; e-mail: sv.olkhovych@ukr.net)

O.V. Krokhtiak Candidate of Economic Sciences Institute of Agroecology and Environmental Management of NAAS (Ukraine, Kyiv; e-mail: lesja26051988@gmail.com)

\section{ANALYSIS OF THE PRODUCTION OF MEDICINAL PLANTS IN UKRAINE}

This article analyzes the status of producing medicinal plant raw materials in Ukraine. The efficiency of using phyto diversity of the flora for medical purposes in our country is one of the highest in the world. The most common medicinal plants are valerian, dog rose, tricolor violet, salvia, dandelion, oregano, lesser periwinkle, wild strawberry, chamomile, etc. The following areas are favorable for growing and collecting medicinal raw materials: Carpathian, Forest-Steppe, Polissya, unfavorable - Steppe zone. Due to unfavorable weather conditions during 2006-2016 the preparation of medicinal raw materials decreased in 5.5 times. The largest companies that relared to medicinal plant materials are: LLC Fitosvit LTD (growing and selling medicinal herbs and plants in bulk), CJSC Liktravy (Zhytomyr) (producing phytopreparations and phytoteas), OJSC Halychpharm (producing finished medicines on the basis of herbal raw material extraction), Sumyfitofarmacia (growing, collection, processing, production and supply of raw materials for tea). The largest enterprises of growing medicinal plant raw materials are geographically located in Poltava, Kherson, Rivne, Odessa, Chernihiv, Cherkasy, Donetsk regions.

Key words: medicinal plants, plant raw materials, sowing acreage, production amounts.

\section{REFERENCES}

1. The Verkhovna Rada of Ukraine (2002), The Law of Ukraine «On seeds and planting material». Retrieved from: http://zakon.rada.gov.ua/laws/show/411-15 (date of accesse: 19.02.2019).

2. Fudychko, O.I. \& Pauk, M.F. (1998). Likarski ta medonosni roslyny Halychyny [Medicinal and honey plants of Galicia]. Lviv: Svit. 128. (In Ukr.) 
3. Zvit pro naukovo-doslidnu robotu (2016). Likarski roslyny shcho mistiat alkaloidy ta mozhut buty vyroshcheni z nasinnievoho materialu DSLR IAP NAAN [Medicinal plants containing alkaloids and can be grown from seed of the ESMP IAEM NAAS]. Berezotocha. 24. (In Ukr.)

4. Likarski roslyny, yikh poshyrennia ta zastosuvannia [Medicinal plants, their distribution and use]. [Electronic source]. URL: http://www. likarski-travi.ks.ua (In Ukr.).

5. Hrodzinskyi, A.M. (1992). Likarski roslyny: Entsyklopedychnyi dovidnyk [Medicinal plants: Encyclopedic reference book]. K.: «Ukrainska radianska entsyklopediia». 544. (In Ukr.)

6. Marketingovaya kompaniya Sinergiya (2017). Obzor rynka lekarstvennogo rastitelnogo syrya Ukrainy 2016: analiticheskij sbornik [Market research of medicinal plant materials of Ukraine 2016: analytical compilation]. 38. (In Ukr.)

7. Porada, O.A. (2011). Henetychni resursy likarskykh roslyn: zberezhennia vyvchennia ta vykorystannia [Genetic resources of medicinal plants: conservation, study and use]. Henetychni resursy roslyn [Plant Genetic Resources], 9, 27-36. (In Ukr.)

8. Semak, B.B., Barna, M.Yu. and Demkevych, L.I. (2011). Vitchyznianyi rynok likarskoi roslynnoi syrovyny: problemy i rishennia [Domestic market of medicinal plant raw materials: problems and solutions]. Naukovyi Visnyk NLTU Ukrainy [Scientific Bulletin of NLTU Ukraine], 21.1, 264-268. (In Ukr.)

9. Nykytiuk, Yu.A. (2017). Ekoloho-ekonomichni zasady rozvytku rynku likarskoi roslynnoi syrovyny $v$ Ukraini [Ecological and economic principles of development of the market of medicinal plant raw materials in Ukraine]: dys. ... doct. ekon. nauk: 08.00.06 / Kyiv: Institute of Agroecology and Environmental Management of NAAS, 452. (In Ukr.)

10. The official site of the State Statistics Service of Ukraine. [Electronic source]. URL: http://www.ukrstat. gov.ua/ (In Ukr.)

11. Solohub, Yu.O. (2018). Ekoloho-ekonomichnyi mekhanizm zbalansovanoho rozvytkulikarskoho roslynnytstva [Ecological and economic mechanism of balanced development of medicinal plants]: dys. ... kand. ekon. nauk: 08.00.06 / Kyiv: Institute of Agroecology and Environmental Management of NAAS, 204. (In Ukr.)

12. Mirzoieva, T.V. (2018). Osoblyvosti eksportu-importu produktsii likarskoho roslynnytstva v umovakh sohodennia [Features of export-import of medicinal plant products in the present conditions]. Biznesinform [Businessinform], 7, 32-37. [Electronic source]. URL: http://www.business-inform.net/export_pdf/business-inform-2018-7_0-pages-32_37.pdf (In Ukr.)

13. Sudha Narayanan. (2012). Inflectionsin Agricultural Evolution: Contemporary Commodity Complexes and Transactional Formsin Interior Tamil Nadu. Economic \& Political Weekly. [Electronic source]. URL: http://bi.galegroup.com.ezproxy1.lib.asu.edu/global/article/GALE\%7CA313300027?u=asuniv

\section{Authors}

Palianychko Nina Ivanivna - Doctor of Economic Sciences, Senior Research Fellow, Head of the Department of scientific researches coordination of scientific and organizational management, National Academy of Agrarian Sciences of Ukraine (Ukraine, 01010, Kyiv, 9 Mykhailo OmelianovychPavlenko St.; e-mail: spalianychko@ukr.net).

Olkhovych Svitlana Yaremivna - Applicant, Head of the Department of economic research work, Institute of Agroecology and Environmental Management of NAAS (Ukraine, 03143, Kyiv, 12 Metrologichna St.; e-mail: sv.olkhovych@ukr.net).

Krokhtiak Oleksandra Vasylivna - Candidate of Economic Sciences, Head of the Sector of economic analysis research work of department of economic research work, Institute of Agroecology and Environmental Management of NAAS (Ukraine, 03143, Kyiv, 12 Metrologichna St.; e-mail: lesja26051988@gmail.com). 